\title{
Chemical composition and antibacterial activity of Piper lenticellosum C.D.C essential oil collected in Ecuador
}

\author{
María Eugenia Rondón $^{1 *}$, Judith Velasco ${ }^{2}$, Xavier Cornejo $^{3}$, Janeth Fernández ${ }^{2}$, Vladimir Morocho ${ }^{3}$ \\ ${ }^{1}$ Facultad de Ciencias Naturales, Universidad de Guayaquil, Guayaquil, Ecuador. Facultad de Farmacia y Bioanálisis. Universidad de Los Andes, Mérida, \\ Venezuela. ${ }^{2}$ Facultad de Farmacia y Bioanálisis. Universidad de Los Andes, Mérida, Venezuela. ${ }^{3}$ Herbario GUAY, Universidad de Guayaquil, Facultad de \\ Ciencias Naturales, Guayaquil, Ecuador. ${ }^{4}$ Departamento de Química. Universidad Técnica Particular de Loja, Ecuador.
}

\begin{tabular}{|c|c|}
\hline ARTICLE INFO & ABSTRACT \\
\hline Article history: & \multirow{6}{*}{$\begin{array}{l}\text { The essential oil of the leaves and spikes of Piper lenticellosum C. DC. (Piperaceae) was isolated by } \\
\text { hydrodistillation and analyzed by GC/MS. A yield of } 2.06 \% \text { was obtained. Twenty eight components were } \\
\text { identified by comparison of their mass spectra with Wiley GC-MS library data and the retention indices (RI) } \\
\text { calculated for every compound. The major constituents were piperitone }(33.97 \%), 1,8 \text { cineole }(11.92 \%) \text {, } \\
\text { limonene }(11.07 \%) \text {, safrole }(8.18 \%) \text { and } \alpha \text {-pinene }(4.49 \%) \text {. Antibacterial activity of the essential oil was } \\
\text { evaluated against five important human pathogenic bacterial strains using the disk diffusion agar method. The } \\
\text { results showed at moderate activity against Staphylococcus aureus ATCC (25923), Escherichia coli ATCC } \\
(25922) \text { and Klebsiella pneumoniae ATCC (233357) with minimal inhibitory concentration (MIC) values of } \\
100,200 \text { y } 300 \mu \mathrm{L} / \mathrm{mL} \text {, respectively. According to the literature consulted, this is the first report on chemical } \\
\text { composition and antibacterial activity of the essential oil of Piper lenticelosum C. DC. from Ecuador. }\end{array}$} \\
\hline Received on: 13/06/2016 & \\
\hline Revised on: 07/07/2016 & \\
\hline Accepted on: 28/07/2016 & \\
\hline Available online: $30 / 08 / 2016$ & \\
\hline $\begin{array}{l}\text { Key words: } \\
\text { Piper lenticellosum, } \\
\text { Piperaceae, piperitone, } \\
\text { essential oil, antibacterial } \\
\text { activity. }\end{array}$ & \\
\hline
\end{tabular}

\section{INTRODUCTION}

The genus Piper L. (Piperaceae) comprises more than 700 species widely distributed in the tropical and subtropical regions of the world (Jaramillo and Manaos, 2001); and is known for its economic importance due at its aromatic and medicinal properties (Ravindran, 2000). Particularly, in Ecuador 275 Piper species have been reported, 75 of which are endemic to the country (Callejas, 1999; Quijano et al., 2006). Traditionally, Piper species have been used in Latin America as analgesics in pain management, toothache and wound treatment (Parmar et al., 1997). In Ecuador, some of this species have been used in folk medicine to treat numerous diseases as bronchitis, dysmenorrheal, anti-diarrheal, anti-parasitical, renal diseases and the leaves bath against several indispositions (Grandtner and Chevrette, 2013). The essential oils of Piper species have been

* Corresponding Author

María Eugenia Rondón, Faculty of Natural Sciences, University of Guayaquil, Guayaquil, Ecuador. Email: rondonr@ula.ve recognized for showing insecticidal, bactericidal, larvicidal, molluscicidal, cytotoxic, anticholinesterasic and leishmanicidal activities (da Silva et al., 2014; Morales et al., 2013). The chemical composition of essential oil of some Piper species have been analyzed showing as main compounds phenylpropanoids such as safrole, dillapiol and myristicin and terpenes such as limonene, $\beta$ caryophyllene, spathulenol, $(E)$-nerolidol, $\alpha$-bicyclogermacrene and cadinol (Maia et al., 2009; Moura do Carmo et al., 2012). Piper lenticellosum C. DC., has been cited as a synonym of $P$. carpunya Ruiz \& Pav. (Jorgensen \& León, 1999), it is known in Ecuador as "guaviduca", and has been used in traditional medicine as anti-inflammatory, anti-ulcer, anti-diarrheal and anti-parasitical remedy as well as a treatment for skin irritations (Diaz and Dorado, 1986).

Despite the wide numbers of studies on chemical composition from Piper species, a single report on essential oil of Piper carpunya from Peruvian Amazon is available (Vargas et al., 2004). Anti-secretory, anti-inflammatory and anti-Helicobacter pylori activities such as antioxidant activities of the ethanolic extract of $P$. carpunya have also been studied. 
These activities have been associated with the presence of flavonoids isolated from leaves of this species such as vitexin, isovitexin, rhamnopyranosylvitexin, isoembigenin also the phytosterols and phytol triterpenes (De las Heras et al., 1998; Quílez et al., 2010). In our continuing interest for the evaluation of biological proprieties and chemical composition of the medicinal plant that grows spontaneously in the Coast of Ecuador, the chemical composition and antibacterial activity of the essential oil of Piper lenticellosum C.D.C has been studied.

\section{MATERIALS AND METHODS}

\section{Plant Materials}

The leaves and spikes of Piper lenticellosum C. DC. were collected in July 2015 at Matilde Esther locality, Guayas Province, Ecuador. Botanical identification was carried out by Ricardo Callejas (HUA), and a voucher specimen (code MER01) has been deposited at the GUAY Herbarium, Faculty of Natural Science, University of Guayaquil, Ecuador.

\section{Essential oils Isolation}

Fresh leaves and spikes (300 g) were subjected to hydrodistillation for $4 \mathrm{~h}$, using a Clevenger-type apparatus. The oils $(6.2 \mathrm{~mL}, 2.06 \%)$ were dried over anhydrous sodium sulfate and stored in sealed vials at $4{ }^{\circ} \mathrm{C}$ in the dark until analyzed and tested.

\section{Gas chromatography (GC/FID)}

The analyses of the chemical composition of the essential oil were performed on Agilent gas chromatograph (model $6890 \mathrm{~N}$ series) equipped with a flame ionization detector (FID) using a non-polar DB-5MS (5\% phenyl-methylpolyxilosane) $30 \mathrm{~m}$ x 0.25 $\mathrm{mm}$, thickness $0.25 \mu \mathrm{m}$ capillary column (Agilent 122-5532). An automatic injector (series 7683) in split mode was used. The sample, $1 \mu \mathrm{L}$ of solution (1/100, v/v, essential oil/dicloromethane), was injected with a split ratio of 1:50. The initial oven temperature was held at $50{ }^{\circ} \mathrm{C}$ for 3 minutes, then it was heated to $210{ }^{\circ} \mathrm{C}$ with a ramp of $2.5{ }^{\circ} \mathrm{C} / \mathrm{min}$, and the temperature was maintained for $3 \mathrm{~min}$ until the end. The injector and detector temperatures were $210{ }^{\circ} \mathrm{C}$ and $250{ }^{\circ} \mathrm{C}$, respectively. Helium was used as a carried gas at $0.9 \mathrm{~mL} / \mathrm{min}$ in constant flow mode. The retention index was determined based on the retention times of the standard hydrocarbons TPH-6RPM of CHEM SERVICE C9-C24, which were injected after the oils under the same conditions.

\section{Gas chromatography-mass spectrometry (GC-MS)}

The GC-MS analyses were performed using an Agilent gas chromatograph coupled to a mass spectrometer detector (model Agilent series 5973 inlet). The spectrometer was operated at $70 \mathrm{eV}$, electron multiplier $1600 \mathrm{eV}$, scan rate: $2 \mathrm{scan} /$ second and mass range: $40-350 \mathrm{~m} / \mathrm{z}$. This was provided with a data system MSD-Chemstation D.01.00 SP1. The GC equipped with a DB$5 \mathrm{MS} 5 \%$ phenyl-methylpolysiloxane capillary column $(30 \mathrm{~m} \mathrm{x}$ $0.25 \mathrm{~mm} \times 0.25 \mu \mathrm{m})$. The ion source temperature was $250^{\circ} \mathrm{C}$. The constituents of the essential oil were identified by comparison of their mass spectra with reference spectra in the computer library (Wiley) and also by comparing their retention indices, with those authentic compounds or data in the literature (Adams, 2007; Joulain and Konig, 1998). The quantitative data were obtained electronically from FID area percentage without the use of correction factor.

\section{Antimicrobial method}

The antimicrobial activity was carried out according to the disc diffusion assay described by Velasco et al., 2007. The strains were maintained in agar at room temperature. Each bacterial inoculum $(2.5 \mathrm{~mL})$ was incubated in Müeller-Hinton broth at $37^{\circ} \mathrm{C}$ for 18 hours. The bacterial inoculum was diluted in sterile $0.85 \%$ saline to obtain turbidity visually comparable to a McFarland $\mathrm{N}^{\circ} 0.5$ standard $\left(10^{6-8} \mathrm{CFU} / \mathrm{mL}\right)$. The minimal inhibitory concentration (MIC) was determined only with microorganisms that displayed inhibitory zones. MIC was determined by dilution of the essential oil in dimethyl sulphoxide (DMSO) pipetting $10 \mu \mathrm{L}$ of each dilution onto a filter paper disc. Dilutions of the oil within a concentration range of $20-980 \mu \mathrm{L} / \mathrm{mL}$ were also carried out. MIC was defined as the lowest concentration that inhibited visible bacterial growth (CLSI, 2016). A negative control was also included in the test using a filter paper disc saturated with DMSO $(10 \mu \mathrm{L})$ to check possible activity of this solvent against the assayed bacteria. The experiments were repeated at least twice.

\section{RESULTS AND DISCUSSION}

The essential oil was analyzed by Gas Chromatography (GC) and Gas Chromatography-Mass Spectrometry (GC-MS). All components (28, representing $98.78 \%$ of the total oil) were characterized by comparison of each MS with the Wiley GC/MS library data also from its retention index (RI). A list of the identified components, along with their percentage of the total oil, is given in Table 1 .

The chemical composition of the essential oil was characterized by a high percentage of oxygenated monoterpenes $(53.90 \%)$ and monoterpenes hydrocarbons $(31.11 \%)$ while that the fraction corresponding to sesquiterpenes was very poor $(0.46$ $\%)$. The most abundant compounds in the oil were piperitone (33.97\%), 1,8 cineole (11.92\%), limonene (11.07\%), safrole $(8.18 \%)$ and $\alpha$-pinene $(4.49 \%)$. In addition, 8-acetoxycarvotanacetone $(3.83 \%), \quad p$-cymene $(3.57 \%)$, $\alpha$-terpinene $(3.11 \%), \beta$-pinene $(2.86 \%)$ and ascaridole $(2.60 \%)$ were also detected. These data collected were relatively discordant with the only report available in the literature on the essential oil of $P$. carpunya (syn. P. lenticellosum) from Peruvian Amazon which showed as major compounds $\alpha$-terpinene (12.1\%), p-cymene $(10.9 \%), 1,8$-cineole $(13.0 \%)$ and safrole $(14.9 \%)$ from the leaves, while that $\alpha$-terpinene $(9.8 \%)$, p-cymene $(7.7 \%), 1,8$-cineole $(30.2 \%)$ and safrole $(32.0 \%)$ from the spikes. Piperitone was not observed in the Peruvian species (Vargas et al., 2004). These 
results evidenced a possible phytochemical intraspecific variability.

Table 1. Chemical composition of the essential oil of Piper lenticellosum C.D.C

\begin{tabular}{|c|c|c|c|c|c|}
\hline $\begin{array}{c}\text { Peak } \\
\text { No }\end{array}$ & Compounds $^{\mathrm{a}}$ & $\% \mathrm{~A}$ & RT & $\mathbf{K} \mathbf{I}_{\text {cal }}$ & $\mathbf{K} \mathbf{I}_{\text {tab }}$ \\
\hline 1 & $\alpha$-Thujene & 0.22 & 5.24 & 924 & 924 \\
\hline 2 & $\alpha$-Pinene & 4.49 & 5.42 & 930 & 932 \\
\hline 3 & Camphene & 0.53 & 5.76 & 943 & 946 \\
\hline 4 & Sabinene & 1.80 & 6.32 & 962 & 969 \\
\hline 5 & $\beta$-Pinene & 2.86 & 6.42 & 965 & 974 \\
\hline 6 & $\beta$-Myrcene & 1.43 & 6.70 & 974 & 988 \\
\hline 7 & $\delta$-2-Carene & 0.22 & 6.99 & 993 & 1001 \\
\hline 8 & $\alpha$-Phellandrene & 0.87 & 7.09 & 996 & 1002 \\
\hline 9 & $\alpha$-Terpinene & 3.11 & 7.42 & 1005 & 1014 \\
\hline 10 & $p$-cymene & 3.57 & 7.64 & 1013 & 1020 \\
\hline 11 & limonene & 11.07 & 7.77 & 1019 & 1024 \\
\hline 12 & 1,8-Cineole & 11.92 & 7.87 & 1023 & 1026 \\
\hline 13 & $\gamma$-Terpinene & 0.94 & 8.60 & 1045 & 1054 \\
\hline 14 & cis-Sabinenehydrate & 0.31 & 8.87 & 1056 & 1065 \\
\hline 15 & Linalool- L & 2.39 & 9.81 & 1093 & 1095 \\
\hline 16 & Camphor & 0.72 & 11.28 & 1144 & 1141 \\
\hline 17 & Citronellal & 0.23 & 11.48 & 1150 & 1148 \\
\hline 18 & Terpinen-4-ol & 0.60 & 12.31 & 1175 & 1174 \\
\hline 19 & Ascaridole & 2.60 & 14.31 & 1240 & 1237 \\
\hline 20 & Carvone & 0.38 & 14.47 & 1245 & 1239 \\
\hline 21 & Piperitone & 33.97 & 14.93 & 1260 & 1249 \\
\hline 22 & $\alpha$-Terpinen-7-al & 0.78 & 15.78 & 1287 & 1283 \\
\hline 23 & Safrole & 8.18 & 15.93 & 1291 & 1285 \\
\hline 24 & Carvacrol & 0.58 & 16.28 & 1302 & 1298 \\
\hline 25 & $\alpha$-Terpinelyl acetate & 0.41 & 17.84 & 1352 & 1346 \\
\hline 26 & $p$-cymen-7-ol-acetate & 0.31 & 20.11 & 1422 & 1421 \\
\hline 27 & Germacrene-D & 0.46 & 21.96 & 1486 & 1484 \\
\hline \multirow[t]{8}{*}{28} & 8-acetoxy-carvotanacetone & 3.83 & 24.48 & 1565 & 1564 \\
\hline & Monoterpene hydrocarbons & & 31.11 & & \\
\hline & Oxygenated monoterpenos & & 53.90 & & \\
\hline & Sesquiterpene hydrocarbons & & 0.46 & & \\
\hline & Oxygenated Sesquiterpenes & & 0 & & \\
\hline & Phenylpropanoids & & 8.76 & & \\
\hline & Other compounds & & 4.55 & & \\
\hline & Total identified & & 98.78 & & \\
\hline
\end{tabular}

${ }^{\mathrm{a}}$ Compounds are listed in sequence from DB-5MS column elution

${ }^{\mathrm{b}}$ Kovats retention indices (RI) were calculated against $\mathrm{C}_{9}$ to $\mathrm{C}_{24} n$-alkanes Series on a DB-5MS column.

Some chemical polymorphism to Piper genus is known. In Bolivia, for example, the main constituent is 1,8-cineol (40\%), while that a chemotype frequently found in the Americas the dillapiol is predomint (30-90\%) (Guerrini et al., 2009). Safrole and other alkylbenzenes are present in percentage significantly high in some species of Piper genus such as P. obliquum Ruiz \& Pav. (safrole, $45.8 \%$ ) and P. aduncum L. (dillapiol, 45.9\%), both species from eastern of Ecuador (Guerrini et al., 2009); $P$. hispidinervum C. DC. (safrole, $85.08 \%$ ) (Aumeeruddy-Elalfi et al., 2015); P. betle L. (safrole, 48.06\%) (Telci et al., 2010) among others. However, safrole in the essential oil of $P$. lenticellosum was relatively low $(8.18 \%)$ and dillapiol was not observed.

Additionally, this clear difference between the two essentials oils might be due to climatic conditions. It is well documented that essential oils yield vary considerably depending on the time of the year of plant collection and is also influenced by environmental conditions at the time of harvesting (Juliani et al., 2002). However, this species are widely used in traditional medicine in Ecuador, Colombia and Perú (Grandtner and Chevrette, 2013).

Antibacterial activity of Piper lenticellosum essential oil was screened against international reference bacterial strains and results obtained are summarized in Table 2. The essential oil showed a significantly inhibition of the growth of the bacterial strains producing a zone of inhibition ranging from 7 to $17 \mathrm{~mm}$ with MIC values ranging from 100 to $900 \mu \mathrm{L} / \mathrm{mL}$. These results showed that the essential oil was most active against $S$. aureus, $E$. coli and K. pneumoniae with MIC values ranging 100, 200 and $300 \mu \mathrm{L} / \mathrm{mL}$, respectively. The antibacterial activity of the essential oil of $P$. lenticellosum could be due to the presence of piperitone, the major component of the oil $(33.97 \%)$. The antibacterial properties of the piperitone have been reported (Mahboubi and Haghi, 2008) thus as the capacity as nitrofurantoin resistance modulating agent (Shahverdi et al., 2015). Additionally, other Piper species have showed antibacterial activity against different Gram positive and Gram negative bacteria related at presence to monoterpens as $\alpha$-pinene and $\beta$-pinene (Morales et al., 2013); alkylbenzenes as safrole (Guerrini et al., 2009) that are also present in the essential oil of $P$. lenticellosum. To the best of our knowledge, this is the first report on the antibacterial activity of the essential oils $P$. lenticellosum from Ecuador. With these results, we hope to contribute to the study of species of the genus Piper from Ecuador, of which many are used since ancient times by the Ecuadorian population.

Table 2: Antibacterial activity of the essential oil of Piper lenticellosum C.D.C.

\begin{tabular}{|c|c|c|c|c|c|c|c|}
\hline \multirow{3}{*}{ Microorganisms } & \multicolumn{6}{|c|}{ Inhibition Zone (mm)* } & \multirow{3}{*}{$\begin{array}{c}\text { MIC } \\
(\mu \mathrm{L} / \mathbf{m L})\end{array}$} \\
\hline & \multirow{2}{*}{$\begin{array}{c}\text { Essential } \\
\text { oil }\end{array}$} & \multicolumn{5}{|c|}{ Reference compounds } & \\
\hline & & OX & VA & CFX & AZT & IMP & \\
\hline Staphylococcus aureus ATCC (25923) & 17 & 26 & & & & & 100 \\
\hline Enterococcus faecalis ATCC (29212) & 7 & & 19 & & & & 900 \\
\hline Escherichia coli ATCC (25922) & 13 & & & 20 & & & 200 \\
\hline Klebsiella pneumoniae ATCC (23357) & 9,5 & & & & 26 & & 300 \\
\hline Pseudomonas aeruginosa ATCC (27853) & 8 & & & & & 24 & 800 \\
\hline
\end{tabular}

*Inhibition Zone, diameter measured in $\mathrm{mm}$, disc diameter $6 \mathrm{~mm}$, average of two consecutive assays.

OX: Oxacilin ${ }^{\circledR}$ BBL $^{\mathrm{TM}}(1 \mu \mathrm{g})$; VA: Vancomycin ${ }^{\circledR}$ Himedia $(30 \mu \mathrm{g})$; CFX: Cefuroxime ${ }^{\circledR}$ Oxoid $(30 \mu \mathrm{g})$; AZT: Aztreonam ${ }^{\circledR}$ Oxoid $(30 \mu \mathrm{g})$; IMP: Imipenem ${ }^{\circledR}$ $\mathrm{BBL}^{\mathrm{TM}}(10 \mu \mathrm{g})$; MIC: Minimal inhibition concentration, concentration range $20-980 \mu \mathrm{L} / \mathrm{mL}$. 


\section{CONCLUSION}

In the present research, several differences were observed in the composition of $P$. lenticellosum essential oil comparing to Piper carpunya (Vargas et al., 2004), this might be attributed to geographical environment, seasonality, physiological age of the plant, harvesting time, among other conditions. The essential oil showed a broad spectrum against both Gram positive and Gram negative bacteria attributed to piperitone, mainly. These results may explain the use of these species in the traditional medicine as anti-diarrheal, bronchitis and skin conditions.

It must also consider that these apparent differences in the chemical composition may be due to P. lenticellosum should be treated as a related but separate species and not as a synonym for $P$. carpunya. Phylogenetic and molecular studies are recommended for both species.

\section{ACKNOWLEDGEMENT}

Authors wish to acknowledge Secretaría Nacional de Educación Superior, Ciencia, Tecnología e Innovación (SENESCYT), Ecuador for the sponsorship throughout Prometeo project.

\section{REFERENCES}

Adam R. 2007. Identification of the essential oil components by GC/MS. Allured Publishing Corporation, Carol Stream, Il, USA.

Aumeeruddy-Elalfi Z, Gurib-Fakim A, Mahomoodally F. Antimicrobial, antibiotic potentiating activity and phytochemical profiles of essential oils from exotic and endemic medicinal plants of Mauritius. Ind Crops Prod, 2015; 71: 197-204.

Callejas R. 1999. Catálogo de las Plantas Vasculares de Ecuador. Jorgensen \& Susana León, St. Louis, USA.

Clinical and Laboratory Standards Institute. CLSI (2016) Performance standards for antimicrobial susceptibility testing; Sixteenth informational supplement. Methods for dilution antimicrobial susceptibility test for bacteria that grow aerobically; Approved standard. M7-A7. Clinical and Laboratory Standards Institute, Wayne, PA.

Da Silva JKR, Pinto LC, Burbano RMR, Montenegro R C, Guimaraes E F, Andrade H A, Maia JG. Essential oils of Amazon Piper species and their cytotoxic, antifungal, antioxidant and anti-cholinesterase activities. Ind Crops Prod, 2014; 58: 55-60.

De la Heras B, Slowing K, Benedi J, Carretero E, Ortega T, Toledo C, Bermejo P, Iglesias I, Abad MJ, Gómez-Serranillos P, Liso PA, Villar A, Chiriboga X. Antiinflammatory and antioxidant activity of plants used in traditional medicine in Ecuador. J Ethnopharmacol, 1998; 61: 161-166.

Díaz PP, Dorado V. Constituyentes químicos de las hojas de Piper lenticellosum C.D.C. Rev Latinoam Quim, 1986; 17: 58-60.

Grandtner MM, Chevrette J. 2013. Dictionary of trees. South America. Nomenclatura, Taxonomy and Ecology. Quebec: Elsevier.

Guerrini A, Sacchetti G, Rossi D, Paganetto G, Muzzoli M, Andreotti E, Tognolini M, Maldonado ME, Bruni R. Bioactivities of Piper aduncum L. and Piper obliqum Ruiz \& Pavon (Piperaceae) essential oils from Eastern Ecuador. Environ Toxicol Pharmacol, 2009; 27: 39-48.
Jaramillo MS, Manaos PS. Phylogeny and patterns of floral diversity in the genus Piper (Piperaceae). Am J Bot, 2001; 88:706-716.

Juliani HR, Kroch AR, Juliani HR, Trippi VS, Zygadlo JA. Intraspecific variation in the leaf oils of Lippia junelliana (Mold). Tronc. Ecology, 2002; 30: 163-170.

Joulain D, Konig W. 1998. The Atlas of Spectral Data of Sesquiterpene Hydrocarbons. Hamburg, Germany: E. B. Verlag,.

Kovats E. 1965. Advances in chromatography. New York: Giddings JC, Keller RA., Marcel Dekker

Maia JGS, Andrade EHA. Database of the Amazon aromatic plants and their essential oils. Quim. Nova, 2009; 32: 595-622.

Mahboubi M, Haghi G. Antimicrobial activity and chemical composition of Mentha pulegium L. essential oil. J Ethnopharmacol, 2008; 119: 325-327.

Morales A, Rojas J, Moujir L, Araujo L, Rondón M. Chemical composition, antimicrobial and cytotoxic activities of Piper hispidum Sw. essential oil collected in Venezuela. J App Pharm Sci, 2013; 3: 16-20.

Moura do Carmo D, Fernandes AC, Machado GMC, Leon LL, Rocha de Andrade S. Chemical and Biological Analyses of the Essential Oils and mains Constituents of Piper Species. Molecule, 2012; 17: 1819 1829.

Parmar VS, Jain SC, Bisht KS, Jain R, Taneja P, Jha A, Tyagi OD, Prasad AK, Wengel J, Olsen CE, Boll PM. Phytochemistry of the Genus Piper. Phytochem, 1997; 46: 597-673.

Quijano-Abril MA, Callejas-Posada R, Miranda-Esquivel DR. Areas of endemism and distribution pattern for Neotropial Piper species (Piperaceae) J Biogeograp, 2006; 33: 1266-1278.

Quílez A, Berenguer B, Gilardoni G, Souccar C, de Mendoncar S, Oliveira LFS, Martín-Calero MJ, Vadini G. Anti-secretory, antiinflammatory and anti-Helicobacter pylori activities of several fractions isolated from Piper carpunya Ruiz\&Pav. J Ethnopharmacol, 2010; 128: 583-589.

Ravindran PN. 2000. Black pepper: Piper nigrum; Medicinal and Aromatic Plants. Industrial Profiles. Kerala, India. Center for Medicinal Plants Research.

Shahverdi AR, Mirzaie S, Rafii F, Kakavand M, Foroumadi A. Monoterpenes as nitrofurantoin resistance modulating agents: minimal structural requirements, molecular dynamics simulations, and the effect of piperitone on the emergence of nitrofurantoin resistence in Enterobacteraceae. J Mol Model, 2015; 21: 198.

Telci I, Demirtas I, Bayram E, Arabaci O, Kacar O. Environmental variation on aroma components of pulegone/piperitone rich spearmint (Mentha spicata L). Ind Crop Prod, 2010; 32: 588-592.

Vargas L, Velasco-Negueruela A, Pérez-Alonso M, Palá-Paúl J, García M. Essential oil composition of the leaves and spikes of Piper carpunya Ruiz \& Pavon (Piperaceae) from Perú. J Essential Oil Res, 2004; 16: $122-123$.

Velasco J, Rojas J, Salazar P, Rodríguez M, Díaz T, Morales A, Rondón M. Antibacterial activity of the essential oil of Lippia oreganoides against multiresistant bacterial strains of nosocomial origin. Nat Prod Commun. 2007; 2: 85-88.

\section{How to cite this article:}

Rondón ME, Velasco J, Cornejo X, Fernández J, Morocho W. Chemical composition and antibacterial activity of Piper lenticellosum C.D.C essential oil collected in Ecuador. J App Pharm Sci, 2016; 6 (08): 156-159. 